Article

\title{
Spirit Confronts the Four-Headed Monster: Jean-Bertrand Aristide's Mistik-Infused Flood-Rise in Duvalierist Haiti
}

\author{
Geoffrey Kain
}

Honors Program, Embry-Riddle Aeronautical University, Daytona Beach, FL 32114, USA; kaing@erau.edu

Received: 31 October 2020; Accepted: 8 December 2020; Published: 15 December 2020

\begin{abstract}
To explore Jean-Bertrand Aristide's rise from obscure rural Haiti to become the nation's first democratically elected president—-by a landslide—is to enter into a world and a swirl of events that reads like surreal fiction or magical realism. As a Catholic priest (Salesian order), Aristide was fueled by the religio-socialist principles of liberation theology, which emerged as a significant force in Latin America primarily in the 1970s and 1980s, forcefully and vocally advocating for the masses of Haitian poor mired in deeply-entrenched disenfranchisement and exploitation. As a charismatic spokesperson for the popular democratic movement in Haiti during an era of entrenched dictatorship and repressive violence, Aristide boldly confronted the "four-headed monster" of the Haitian power structure - the army, the church hierarchy, the tontons macoutes, and the wealthy elite. His seemingly impossible escape from multiple assassination attempts, together with the power of his colorful rhetoric and his close association with urban slum dwellers and rural peasants, led to a rising "flood" (or lavalas) that invested him with an aura of Spirit, or mistik, that in either/both the Haitian-embraced tradition of Christianity or vodoun (voodoo) served to energize and greatly reassure an intense mass movement arrayed against seemingly impossible odds. This article focuses on the rise of Aristide as the embodiment and voice of Spirit among the people and does not extend into his tumultuous secular years in and out of the presidency, having been twice the victim of coups (1991 and 2004); instead it focuses primarily on the years 1985-1990 and does not enter into an assessment of Aristide as president. Aristide's own vivid narratives of this time, segments of his sermons, and later, passages of his poetry serve to bolster the literary quality or interpretation of this brief but vividly colorful historic epoch in the Haitian experience.
\end{abstract}

Keywords: Jean-Bertrand Aristide; Haiti; Duvalierism; liberation theology

[Haiti is] a country where surrealism is a fact of life in such a way that the impossible is rampant and the possible scarce. (Franck Laraque, Foreword to Alex Dupuy's The Prophet and the Power: Jean-Bertrand Aristide, the International Community, and Haiti). (Dupuy 2007)

Writing from South Africa, peering back through the filter of more than two hundred years of history, through the filter of his exile as (twice) ousted president of Haiti, through the filter of his expulsion as a Catholic priest excised from the Salesian order, through the filter of his disconnection from the desperately poor of Port-au-Prince among whom he closely and deeply immersed himself perilously for years, Jean-Bertrand Aristide writes (2011):

Since the time that white colonists began

To use Africans to turn Africans into slaves,

With all her heart, Mama Africa has been celebrating 
The courage, strength and pride

Of the children of her entrails. (Aristide 2011, p. 21)

In this poem, "Haïti-Haitii," Aristide explores the meaning of the word, the name of his marginalized, ostracized nation-in Kreyol (translated to English) and in Swahili-from his vantage point as re-defined poet/linguist in exile. ${ }^{1}$ Such brave "children of Africa" include, of course, those of Haiti, the only nation created out of black African slave rebellion, a revolt that erupted in 1791, ultimately realizing the complete overthrow of their French colonial masters, followed by a formal declaration of independence as a nation in 1804. In "The Power of Poetry," Aristide expresses that:

I wish with all my heart

That this philosophical poetry offers

A small contribution to help

The wings of dignity sprout feathers of liberty

Under a giant flag called

MENTAL DECOLONIZATION. (Aristide 2011, p. 20)

Aristide's "small contribution" of this poem follows upon his massive contribution within Haiti as a fearless, inspired voice for the greatly impoverished masses, ${ }^{2}$ the majority of Haitians (whom he regards as enslaved still, but under other masters), in his position as Catholic priest, chiefly through his parish, St. Jean Bosco, situated on the edge of the extensive Port-au-Prince slum of La Saline, which he describes in his 1991 "Letter to My Brothers and Sisters," in In the Parish of the Poor as a place where one must "walk past the children bathing in garbage, past the young half-naked boys ..., past the ... young girls who are trying to sell us their bodies. Let us walk a little further on. Be careful of the mud. Don't slip" (p. 13). He remarks: "You know how hard it is to build Utopia on a garbage heap; indeed, it is hard to build even a poor man's home, and no more corruption, no more inflicted misery, no more children bathing in sewage" (p. 8). While Aristide would never have been so delusional as to contemplate building a utopia in Haiti, he did-principally through his office as priest and using his gifts of impassioned oratory, charisma, erudition, and unflinching courage-focus his energies during the 1980s on catalyzing a popular democratic movement to, ideally, help advance the people from "misery to poverty with dignity," as he often expressed it.

The indignation and anger that motivated Aristide were directed point blank at the Duvalier and Duvalierist ${ }^{3}$ "four-headed monster" often referred to by many Haitians at the time: the army,

1 In exile in South Africa (2004-2011), Aristide completed a Ph.D. in African languages at the University of South Africa, Johannesburg, "while exploring the field of neuro-linguistics, as an honorary researcher ... In addition to Zulu and Swahili, Aristide utilized eight other languages to examine the interactions among multi-lingualism, memory, and emotion" (Asante 3).

2 It is often observed that Haiti is "the poorest nation in the Western hemisphere," with Haiti's economic indicators placing it among various nations of sub-Saharan Africa, Afghanistan, Yemen, and North Korea (GDP per capita rank Haiti as 175 of 193 nations globally). GDP per capita, life expectancy, food insecurity (level of hunger and malnutrition), average daily or monthly wage, etc. all place Haiti very low in relation to other nations of the world and lowest in the West. According to United Nations statistics, Haiti's GDP per capita (in \$US) in 1986 (to consider conditions at the time of Aristide's rise to prominence) was $\$ 468$; most recent data is for 2018 , and Haiti's GDP per capita stands at $\$ 835$, compared to, for example, the United States' $\$ 62,918$. Average life expectancy at birth (both sexes) in the years 1985-1990 for Haitians was 53 years (versus 75 in the United States, by comparison). Infant mortality per 1000 live births (both sexes) in the years 1985-1990 in Haiti was 105.5; in the United States infant mortality per 1000 live births in the years 1985-1990 was 10.2 (United Nations 2020). The Global Hunger Index places Haiti at 111 of 117 nations globally in 2019 (Concern Worldwide and Welthungerhilfe 2020). One in three Haitians "needs urgent food assistance," as pointed out in a recent Reuters article, following from the decline of Haiti's previous food self-sufficiency after the loosening of restrictions on food imports in the 1980s, lowered tariffs, and subsequent import of surplus crops from the United States at prices out of reach for many Haitians, conditions further exacerbated by recent social/political unrest (Marsh and Paultre 2020).

3 Duvalierism refers to the violent and repressive rule exercised by the Duvaliers (1957-71; 1971-86-see note 4, below) and continuation of the same or similar brutally repressive methods during the subsequent rule of successive dictators 1986-1990, then 1991-94. Aristide, as a popular democratic candidate, was reinstated to office from exile in 1994. 
the church hierarchy, the macoutes, ${ }^{4}$ and the wealthy (Farmer [1994] 2006). His close affiliation with the people and being steeped in the native folklore, beliefs, and music himself, together with his intense biblical immersion, international graduate work in psychology and biblical studies, and embrace of liberation theology, all served to cultivate his voice, an emotive poetic style that resonated deeply with a people terrorized and cowed for decades by the ruthless elite power structure. The liberation theology that mobilized many priests throughout Latin America chiefly during the 1970s and 1980s, with its overt emphasis on the "preferential option for the poor," as originally articulated by the Peruvian Fr. Gustavo Gutiérrez, OP, in A Theology of Liberation (Gutiérrez [1971] 1988), was a galvanizing and revolutionary force that led, ultimately, to the assassination of a considerable number of priests and nuns who advocated for the poor via the religio-socialist doctrines that ran counter to the appetites of multi-headed beasts in their respective countries; there is indeed a long list of martyrs and executions, just one notable example among them being the murder of six Jesuits and two others on 16 November 1989, on the campus of the Central American University in San Salvador, El Salvador. As the Reverend Jose Maria Tojeira, the Jesuit Provincial for Central America, reported following the executions: "They were assassinated with lavish barbarity. For example, they took out their brains" (Gruson 1989). Activists throughout the Caribbean and Latin America, such as Aristide, were acutely aware of such stories, and of the intensity and tenacity of those who opposed them. As Michael Löwy noted in 1993, the key social and political events of the time throughout Latin America could not be appreciated nor well understood:

without bearing in mind the profound change that has occurred in Latin American Catholic culture as a result of broad sectors' having embraced and incorporated some of the basic tenets of Marxism ... These developments have been a cause of concern not only for conservative bishops and theologians, defenders of Rome's orthodoxy, and doctrinaires of the faith in in the highest spheres of the Vatican ... but also for the Latin American generals ... (Löwy 1993, p. 28)

The theology's identification with Marxism by its antagonists, as well as some of its own proponents, ${ }^{5}$ placed its advocates in precarious positions vis-a-vis the church establishment, certainly, but also in opposition to rightist and international capitalist interests in the region, not least of which emanated from what Aristide refers to as "the cold, dark country to the North" (Aristide and Wilentz 1990, p. 25), and which Gutiérrez, in A Theology of Liberation, more explicitly addresses. He describes "a new awareness" among reformers:

that there can be authentic development for Latin America only if there is liberation from the domination exercised by the great capitalist countries, and especially by the most powerful, the United States of America. This liberation also implies a confrontation with these groups' natural allies, their compatriots who control the national power structure. (Gutiérrez [1971] 1988, p. 84)

4 The tonton macoutes were named after the Haitian folk-mythical "Uncle Gunnysack," a bogeyman who kidnaps and punishes children by catching them in a gunnysack to be eaten at breakfast. The tonton macoutes were the violent paramilitary arm loyal to François "Papa Doc" Duvalier (President of Haiti from 1957-1971) and then Jean-Claude "Baby Doc" Duvalier (President of Haiti 1971-1986). As explained in "The Tonton Macoutes: The Central Nervous System of Haiti's Reign of Terror" (Council on Hemispheric Affairs 2010), the paramilitary force created by Papa Doc "would report only to him and would be fully empowered to use unremitting violence to maintain the new administration's authority to summarily dispose of its enemies. ... This warlord-led goon squad, ... these torturers, kidnapers, and extortionists were feared ... by the country's general population.... The militia consisted mostly of illiterate fanatics that were converted into ruthless zombie-like gunmen. Their straw hats, blue denim shirts, dark glasses, and machetes remain indelibly etched in the minds of millions of Haitians." The macoutes remained a dominant force throughout the Duvalier years and continued into the post-Duvalier, or Duvalierist, period during which Jean-Bertrand Aristide rose in opposition to them. For the best-known literary evocation of the macoutes, see Graham Greene's novel The Comedians (Greene 1966).

5 In a 1984 New York Times article titled "The Case Against Liberation Theology," Michael Novak cites Nicaraguan priest Ernesto Cardenal as saying that "Christ led me to Marx.... For me, the four Gospels are all equally Communist. I'm a Marxist who believes in God, follows Christ and is a revolutionary for his Kingdom." (Novak 1984). 
This revolutionary expression suggests the "size" of the beast that someone like Aristide (perhaps appropriately a diminutive individual himself, referred to fondly at the time by his many followers as Titid, or the "small one") was setting about to confront. As he recounts in Autobiography, he had been accused of fomenting class struggle. About this he responds:

I did not invent class struggle, no more than Karl Marx did. I would even prefer never to have seen it. Perhaps that is possible, if one never leaves the squares of the Vatican or the heights of Pétionville. But who can avoid encountering class struggle in the heart of Port-au-Prince? It is not a subject of controversy, but a fact, a given ... When some doctor of the faith and (or) of business condemns me by shouting "but you are in favor of class struggle" - therefore a bad priest and a bad citizen-I answer that I am neither for nor against it. Nobody is going to organize a referendum to discover whether the law of gravity is good or bad. It reminds me of the proceedings brought against Galileo to force him to deny the fact that the earth moves. And still, it does move. (p. 106)

Concerning the intersection of liberation theology and Marxism, of religious calling and activism among the poor, Aristide notes that during this era, being branded a "Communist" in Haiti would certainly be to have a target on one's chest:

This land has been stolen by the "big shots," the lawyers, the state. The need for agrarian reform goes without saying. When John Paul II asserted in Haiti, "fòk sa chanje" (things must change), this demand followed from his message. Of course, if I interpret it this way I am immediately branded a communist. "Communist" is a condemnatory epithet, a defamatory accusation that the regime throws in the face of anyone who offers the least opposition. You are labeled a communist: that says everything, there is no appeal from this verdict. You are an enemy of the country, an outlaw, a dog thrown out as prey for public condemnation. Anyone can beat you up—because you are a communist. (Aristide and Wargny 1993, p. 58)

Consistent with Aristide's description, John Quinn cites Archbishop Helder Camara of Brazil as saying: "When I feed the hungry, they call me a saint. When I ask why they have no food, they call me a Communist" (Quinn 1993). As additional context for the David v. Goliath sort of battle that Aristide set himself to, Gutiérrez writes in chapter thirteen of A Theology of Liberation, "Poverty: Solidarity and Protest," that:

... poverty has often been thought of and experienced by Christians as part of the condition-seen with a certain fatalism—of marginated peoples, "the poor," who are an object of our mercy. But things are no longer like this. Social classes, nations, and entire continents are becoming aware of their poverty, and when they see the root causes they rebel against it. The contemporary phenomenon is a collective poverty that leads those who suffer from it to forge bonds of solidarity among themselves and to organize in the struggle against the conditions they are in and against those who benefit from these conditions. (pp. 163-64)

This scenario certainly describes or sets the stage for Aristide's organizing efforts during the middle and late 1980s, relying as he did for his narrative of revolution on both Old and New Testament passages, and combining elements of both liberation theology with echoes of culture-specific vodoun (voodoo) to define/inform his role as liberator, as a "new Dessalines" ${ }^{\prime 6}$ perhaps, even as prophet. As Alex Dupuy describes: "The fusion of mysticism, martyrdom, and anti-makoutism added a messianic character to Aristide, whose humble origins appealed to the masses and won him their immediate

6 Jean-Jacques Dessalines (1758-1806) was a leader of the slave revolution and became the first formal leader of an independent Haiti (using the Arawak name Haïti to replace the previous name of Saint-Domingue). 
devotion" (p. 75). Aristide's immersion among the poor follows from what Celucien Joseph has labeled his "theology of relationality," his deep politico-theological commitment to community and to spiritual integration, just as the Trinity stands as the principal model of Christian integration or relationality. His relational connection with the people together with or embedded in the vision of God as liberator fueled his vision of God working with and through the Haitian poor:

[Aristide] links Jesus' preaching of a "Gospel of Liberation" to the poor with the Exodus narrative in which Yahweh's revolutionary move in history to deliver a colonial subject (the Hebrew slaves) from Egyptian bondage. Israel's deity and Jesus, his Messiah, are clearly portrayed as anti-imperial, anti-colonial, and anti-oppression. It is from this angle that Aristide reconstructs and reappropriates both the Exodus event and Jesus' liberative message in the context of the Haitian poor majority and the marginalized peasants. Yahweh, the God of Slaves, then became the le Dieu pauvre of the Haitian poor, and the Haitian poor became the people of God. Hence, Haiti is "the land" of God's people, the poor ... The re-enactment of the Exodus in the context of the Haitian reality is clear and deliberate in Aristide's political ideology. (Joseph 2014, p. 276)

Thus religious, political, and folk-cultural strands, or personae, if one would choose to regard them as personae, become so tightly interwoven or relational in Aristide's mission, messages, and mistik, in the "Aristide phenomenon," that to understand the syncretism and dissonances informing the "cleansing flood" (lavalas), as the movement (and, later, Aristide's political party) became known, called forth by the tiny priest and that swept him into national power and international attention, is perhaps best evinced through his own vivid, colorful narrative accounts of the time-in his Aristide: An Autobiography (Aristide and Wargny 1993; Wargny 1993) and In the Parish of the Poor: Writings from Haiti (Aristide and Wilentz 1990), the latter containing some of his sermons, often arranged as what may best be considered "performance poetry." The later work Haïti-Haitii? Philosophical Reflections for Mental Decolonization (Aristide 2011; Asante 2011) provides primarily reflections on Haitian and pan-African decolonization, written mostly in verse-again, in Kreyol and Swahili.

Accounts of Aristide's intentions, accomplishments, shortcomings, and failures are routinely polarized and contradictory, particularly after his first election to the office of president. As Aarón Ramos has pointed out: "There is little consensus in both political and academic circles regarding the story of Jean-Bertrand Aristide (Ramos 2008). Some authors emphasize the obstacles that he confronted in his effort to promote equality and political participation of the poor. Others tend to stress his failure to transcend the logic of the Duvalierist state ..." (p. 158). Sifting through the often charged rhetoric leaves one firmly aware, nevertheless, that during his rise to leadership of the popular opposition movement during the waning Duvalier years and beyond, Father Aristide looked directly into the barrel of a gun (literally and figuratively) for a number of years and confronted deeply entrenched structures of power-both secular and religious-with a self-assured faith and popular support that threatened some mainstays of the Western hemispheric status quo with a seismic energy rivaled and surpassed only later by the terrible earthquake of 2010, a catastrophic event from which Haiti has yet to recover.

Aristide attributes his socialist sense as having been first implanted in him by his grandfather, a landowning illiterate peasant who often "played the role of justice of the peace" (Aristide and Wargny 1993, p. 27) mediating disputes. If a peasant had been arrested for stealing a potato or a banana, he would rule that "they took the potato because they were hungry; they have a right to it" (p. 27). Insisting that all men have a right to eat at least once daily, he found himself at times at odds with some of the ruthless section chiefs, whom Aristide later targeted in his reform measures. As he recounts it, his mother deepened this sense of justice and communalism in him, after he, his widowed mother, and his sister left the hills of southwest Haiti and migrated to Port-au-Prince where they "had no fixed residence" and were 
... never less than ten people under one roof ... It was there that I found the sense of, or rather the taste for, community. I feel even today that that brotherhood and sisterhood are something authentically biblical ... They were all my brothers and sisters, just as my companions in struggle would later be, both the young intellectuals and the starving people from the slums. (Aristide and Wargny 1993, p. 31)

Aristide's sense of community and his experience with and identification with the poor fused with his theology from an early age, as he was enrolled in schools operated by the Salesian order beginning at age five (in 1958), and having entered the Salesian seminary in Cap-Haitien (in the north of Haiti) in 1966. His exceptional status as a seminarian and then novice led to his further church-funded study abroad, in the Dominican Republic, Israel, Greece, Italy, and Canada, which bolstered his already firm commitment to serving among the Haitian poor and encouraged his embrace of liberation theology.

Upon his return to Haiti, he became deeply involved in the Ti Legliz ("Little Church"), or ecclesial base communities, in Port-au-Prince, and through this involvement, his reputation, his power, and his trouble grew. As he describes it in In the Parish of the Poor, in his literary narrative style:

Night is falling, but I see a light shining over there, in that little shack over there, with its doors closed. Do you see that slice of light shining out from the cracks in the plywood? Let's go inside. The room inside the little shack is crowded with young people, and a few who are not so young. It's hot. A young woman ... is directing the discussion. What are those words we hear the people saying? Libète. Liberty. Dwa moun. Human rights. Teyoloji liberasyon. Liberation Theology. (Aristide and Wilentz 1990, p. 13)

Such meetings, driven underground by the ruthless Duvalier and Duvalierist paramilitary death squads ready to extinguish any suggestion of resistance or "Communist" organizing, were widespread, and Father Aristide was not only sympathetic, but one who drove and cultivated their understanding of the living gospel's identification with the causes of (and God's presence among) the poor:

What is this place, what is this group, why are they gathered here under the light of one bare bulb to talk about liberty? You know what this is, brothers and sisters, as well as I do. This is an ecclesial base community; in Haiti, we call them ti kominote legliz. Today you can find groups like this all over Latin America; there are more than 300,000 of them in our hemisphere. I work with them, brothers and sisters, and so do you. (p. 13)

The conspiratorial air of the ti legliz-and Aristide's positioning at odds with the church hierarchy-follows from the church administration's collusion with the elite oligarchical power structure that Aristide targeted as the intransigent force committed to maintaining and benefitting from a status quo defined by the rapacious exploitation and oppression of Haiti's mass population of the desperately poor. In his Autobiography, Aristide indicates that, "at the time, bishops and Macoutes walked arm in arm, defending the same causes, but using a different vocabulary to mask their collusion for the benefit of the oligarchy, the banking bourgeoisie without ideals or principles whose profits were invested outside Haiti" (p. 46). As Alex Dupuy characterizes it, Aristide's open rebuke of the Haitian oligarchy and his prioritizing of the poor "inevitably put [him] on a collision course with the Catholic Church hierarchy, for it led him to another conclusion, namely that the Church in Haiti either compromised with the dictatorships or at least preached acceptance of these regimes" (p. 75). As Aristide observes in his Autobiography: "The colonial mission system, having disappeared from all the continents, endures in Haiti. Theology serves to "zombify" the people's spirits in order to subjugate them more readily to traditional sovereignties" (p. 67).

Aristide is even more overt in his scathing critique of church power as he goes beyond the church leaders in Haiti to the Vatican itself. In "The Case Against Liberation Theology," Michael Novak reminds us that Pope John Paul II struggled with the rising force of liberation theology in the heavily Catholic Latin world because of its association with Marxism and his own experience with communism 
in his native Poland. As Novak reports, Leonardo Boff, a Brazilian Franciscan friar and one of the leading figures of the liberation theology movement, was summoned to Rome, after which he remarked that the pope's experience of Marxism is too distant from the Latin American reality: "Marxism is a principally European theme. In Latin America, the big enemy is not Marxism, it is capitalism." (Novak 1984).

Aristide regrets that the Church authorities in Haiti are themselves unwilling to engage with "the liberation church," pressured by the political and moneyed elite, as well as via their clear subordination to Rome:

Often, we fear that the cold behavior of our elder brothers is dictated by another man, a man who lives in another country ... a man who wears white robes and stands, an equal, beside the Church's beloved yellow and white banner. You know which man I mean, brothers and sisters. (Aristide and Wilentz 1990, p. 18)

He moves beyond implication as he notes the "corporate" structure of the church:

From [the pope] at the center extend all powers within the Church throughout the world. That is true. Yet I must remind myself, and my little lamp helps me to remember, he is just a man, a man doing a job ... Just a man doing a job. Now I can see him more clearly. What is the paradigm for the pope in the secular world today? ... Why, it's all too clear. Of course. All the shadows around him, the smoke and mirrors, fall away. Who is this man? He is the chief executive officer of a multinational corporation. And what is the job of a chief executive officer of a multinational corporation? To protect the interests of the company, to ensure its continued existence, to safeguard its officers from dissension $\ldots$, and to provide, at the furthest reach of the corporation, a product that the consumer will purchase. (Aristide and Wilentz 1990, p. 21)

Aristide's animosity toward the church hierarchy was greatly exacerbated by what he clearly saw and experienced as its intentional failure to overtly respond following several deadly attacks on those calling for reform and justice, sometimes while gathered for religious services, sometimes Aristide himself and his parishioners within the sanctuary of St. Jean Bosco. Most notably, the Jean-Rabel massacre: "Peasants marching to protest their condition and to demand an end to their exploitation by the ruling class of their region were cut down and massacred by the military and the agents of the large landholders there. Hundreds were killed; peasants' houses were looted and burned ..." (Aristide and Wilentz 1990, p. 35). In the meantime, Aristide was transferred to a parish filled with "former members of the Tonton Macoutes, generals, the wealthy (the enemies of the Haitian people, in short)" (p. 35). In protest against Aristide's move, a large number of ti legliz youth occupied the cathedral in Port-au-Prince and began a hunger strike. Ultimately, Aristide was reinstated to his parish, while the added focus on him as the leader of an opposition movement increased his personal danger as well as his disenchantment with the church authorities who, he notes bitterly, had failed to denounce the massacre. Indeed, one bishop prior to the massacre had characterized the Jean-Rabel peasants as "troublemakers" (p. 35).

The precariousness of Aristide's life, together with a rising sense of his status as "elect" or "invincible" followed, as twice within two days he somehow survived assassination attempts among what would prove to be multiple assassination attempts. As Christopher Wargny describes Aristide in 1992: "Truly a miraculous survivor of nine failed assassination attempts, he seems more than ever to be the last pure soul in the country" (Introduction). Shortly after the Jean-Rabel massacre, Aristide traveled north to Pont-Sondè to say Mass near the site of the carnage, in an open air tent. In this case, as in several others he describes, Aristide writes of his own sense of what might be called "channeling the Spirit." He reflects that as he said Mass again at his home parish of St. Jean Bosco, immediately prior to departure for the Jean-Rabel memorial service, "the force of life made me say many things that predicted the death that would rain down on us later that same day. I said that I felt as if I were singing 
my own funeral Mass, and I did feel that, but I don't know why" (Aristide and Wilentz 1990, p. 38). Elevated by a sense of solidarity with his fellow worshippers, he "felt that they were leading me by the hand to new heights, to greater courage, to high places from which I would be ... better able to receive the messages that I felt were being sent to me and to them by the force of life, which is God" (Aristide and Wilentz 1990, p. 38). Such a description would easily resonate among the mass of his followers, both in a Christian sense and, as Maya Deren (Deren [1953] 1970) describes in her classic exposition/analysis of vodoun, Divine Horsemen:

Briefly, [Vodoun] proposes that man has a material body, animated by an esprit or gros-bon-ange - the soul, spirit, psyche or self-which, being non-material, does not share death of the body. This soul may achieve the status of a loa, a divinity, and become the archetypal representative of some natural or moral principle. As such, it has the power to displace temporarily the gros-bon-ange of a living person and become the animating force of his physical body. This psychic phenomenon is known as "possession." The actions and utterances of the possessed person are not expressions of the individual, but are the readily identifiable manifestations of the particular loa or archetypal principle. Since it is by such manifestations that the divinities of the pantheon make known their instructions and desires and exercise their authority, this phenomenon is basic to Voudoun, occurs frequently, and is normal both to the religion and to the Haitians. (p. 16)

As Aristide has asserted regarding his understanding of political power: "Sometimes they say politics is money and guns. I believe it is force of spirit" (Farmer [1994] 2006, p.148).

Not long into the Jean-Rabel commemorative service, macoutes arrived and began firing into the gathering. Many were dropping to the ground, wounded or dead, while Aristide was clearly the principal target. He indicates that he was "incapable" of protecting himself and refused to run. "I felt calm, and I stood there, and I saw the gun pointed at me and I saw the smoke coming from the gun and I heard the noise of the bullets. He missed me, and began again, and again I saw the smoke and the bullets, and he missed me again" (Aristide and Wilentz 1990, p. 39). Dragged away to a car and then driven to safety, Aristide merged into another intense near-death experience when, that same night, he and several other priests were stopped during a rain storm at a barricade near an army post by local gangsters and macoutes armed with knives, rocks, and machetes. As they searched the cars, the men were shouting, "Where are the communists? Where is Father Aristide? Give us the communists!" (Aristide and Wilentz 1990, p. 41). With the beatings and demolition that followed, together with preparations to gas and torch the automobile which held Aristide, somehow the carload of battered passengers was able to escape into the night, headlights and windshield shattered. As Aristide again remarks, "The force of life was still with us" (Aristide and Wilentz 1990, p. 41). "Through the story of our triumph over the forces of evil, the people were heartened. If we could face death and not die, then they could face death and not die" (Aristide and Wilentz 1990, p. 46). As part of this triumph, Aristide claims that "in the end, the Macoutes believed that I was invincible and invisible" (Aristide and Wargny 1993, p. 84). Following this escape, Father Aristide and the three priests traveling with him said a Mass of thanksgiving and grace; they invited the Haitian bishops to join them, but "they refused. They refused!" (Aristide and Wilentz 1990, p. 46). The priests said the Mass together, and "thousands came to see us alive before them ... Thousands ... came to hear our voices and be inspired by the force of life" (Aristide and Wilentz 1990, p. 46).

Other riveting accounts of near-martyrdom include Aristide's entering the dreaded Duvalier torture and death chamber, Fort Dimanche, at night, surrounded by stone-faced military personnel, on a mission to request the release of some of his parishioners who had been arrested at a mock-funeral march ("the death of death"; end to brutal repression, etc.). "I knew what beast lived in that hideous fortress. I knew what pain he liked to inflict" (Aristide and Wilentz 1990, p. 33). He-and otherswere fully unsure whether he would re-emerge from the facility since so few did. His re-emergence, with the released prisoners, added to the popular sense of his evident mistik. As Aristide recounts it, yes, 
it was likely beyond naïve for him to walk into "the belly of that beast," but at such moments "it is not you yourself who is readily deciding what you will do, but a part of your spirit, in communion with the spirit of good ... Although it seems that you can choose, in reality you have no choice ... I felt myself to be completely a missionary, completely a servant to the Spirit ... on a mission that went beyond ... what I myself am, and I obeyed, and went to Fort Dimanche ... " (Aristide and Wilentz 1990, p. 31).

As the fated procession passed in front of Fort Dimanche earlier that day, again the bullets began to fly and civilians were cut down, while Aristide broadcast live via the Christian radio station Radio-Soleil: "This was another day when I was supposed to die. The bullets were flying above the jeep, around the jeep" (Aristide and Wilentz 1990, p. 30), and "... the crowd was machine-gunned by the army in front of this sinister building. The shots whistled around my ears. I saw people running or lying flat. A little later, the city trucks came and loaded up the bodies as if they were picking up garbage" (Aristide and Wargny 1993, p. 64).

However, the most notable of the assassination attempts came with the destruction of St. Jean Bosco, again while Aristide was saying Mass. With the escalation of violence realized over recent weeks among the macoutes, Aristide was well aware of the danger and pondered not saying Mass on this particular day, having deep misgivings. After all,

as a symbol of resistance, St, Jean Bosco ... became a target of attack. Brutal treatment was meted out to parishioners, cars were destroyed, individuals placed under suspicion, more and more stones thrown at the modest church, not counting the increasingly frequent efforts at intimidation. There were threats, more threats, constant threats. (Aristide and Wargny 1993, p. 89)

Twenty minutes into the service-attended by as many as two thousand people, roughly one hundred macoutes launched an assault on the church, bombarding it with both stones and bullets. A pregnant woman was shot and killed, others were killed, many were wounded, and the remaining parishioners barricaded the doors, held off attackers with stones and other objects, and fought back for hours, after which the attackers departed (Aristide and Wargny 1993, p. 89-95). Following the battle at St. Jean Bosco, Aristide reflects, with scriptural resonance, on how the survivors filed together out of the parish, while "... the evildoers stood there in the street; they saw us pass and they did not feel me pass; we moved through the midst of them and they were not moved against us ... And we were hidden, by the grace of the Lord" (Aristide and Wilentz 1990, p. 62).

Reflecting on these collective experiences and the unlikelihood of having lived, Aristide is well aware that he may have ended as a martyr, joining other Latin American priests and nuns of the era, and he admits that, "I have sometimes been accused of trying to become a martyr. I love life. I do not want to die, except to help those who are struggling with me. The assassination attempts accelerated the process of consciousness-raising, but I do not go looking for them." He concludes, "But death is a present potential. When I examine the paths of liberation, I know it must be faced" (Aristide and Wargny 1993, p. 82). Considering the multiple escapes from near-certain death, Aristide notes:

Hearing tell of all these events, people have wondered how it is that death did not sweep me away ... But I believe that if you look for the answer to this question with reason only, you will not find it, because the answer lies deeper down and farther away than reason alone can travel. People say it was magic. Some have said the charms of voodoo-my country's other religion—saved us. Well, if you call the work of God magic, then it was magic. (p. 62)

Regarding Christianity, magic, voodoo-even as a Catholic priest, Aristide is inclusive in his religious and civil mission, occasionally minimizing any rigid boundaries between or among the people's sets of beliefs, syncretism being a simple fact of life in Haiti, but not a position that played well with the church authorities: "The accusations that I am a bad Catholic have to do with the company I keep. I have never measured people by their religious affiliation, but solely—if I have a right to 
judge- by their behavior. By the same token, I do not consider voodoo to be an antagonist or an enemy of the Christian faith." He further elaborates:

Orthodox Catholics or well-meaning Westerners consider voodoo to be a complex of superstitions or a catalogue of exotic mysteries ... In the veins of voodoo flows a blood that is Christian. The two are complementary in their opposition to evil. (Aristide and Wargny 1993, p. 68)

Aristide's inclusivity, together with the aura that developed around him through his message and his assassination escapes, and his continuance as the voice of the people, or the spiritual voice to the people, reciprocally, allowed or urged him to rise as leader of the people ("a deep and growing movement over which, as God is my witness, I had no control" (Aristide and Wargny 1993, p. 118), ultimately manifesting in his candidacy for and then election to the office of president in 1990. The Flood had arrived. Faced now with immense and dangerous challenges as a landslide victor (securing $67 \%$ of the vote himself, among a broad slate of candidates), on the shoulders of deliriously hopeful supporters in a revolutionary and historic election - faced or burdened with mammoth public confidence and expectation that he feverishly helped to cultivate-Aristide addresses his messianic image: "It has often been written that I have increasingly regarded myself as a prophet, but I only have the feeling of obeying the word of God and of being the representative of communities that, in themselves, are certainly prophetic" (Aristide and Wargny 1993, p. 120).

Aristide had been criticized generally by his detractors as having a vague agenda as he approached and arrived in office; he countered this by indicating that his was a "simple program: dignity, transparency, participation" (Farmer [1994] 2006, p. 144). His insistence on participation alienated and disturbed the elite, who feared a forced redistribution of land, wealth, and power under Aristide. As the poet Jean-Claude Martineau mused at the time, "Why do the elite hate him so much? All their traditional privileges have been questioned; the way they earn their money, most of the time illegally: drugs, and contraband, and abuse. All of these kinds of things have been questioned, with a very strong possibility of changing the way the country is run: changing the way people perceive power. Because in Haiti the power is an absolute power" (Farmer [1994] 2006, p. 148). Aristide's egalitarian/redistribution ethos and rhetoric, the energy of the message that brought him to the office of president, is epitomized in his metaphor of the table, the banquet, the Supper:

The rich of my country, a tiny percentage of our population, sit at a vast table covered in white damask and overflowing with good food, while the rest of my countrymen and countrywomen are crowded under that table, hunched over in the dirt and starving. It is a violent situation, and one day the people under that table will rise up in righteousness, and knock the table of privilege over, and take what rightfully belongs to them ... It is our mission to help them stand up and live as human beings. That is what we have all been working for for all these years in the parishes of the poor. (Aristide and Wilentz 1990, p. 9)

If this scenario were not clear enough, Aristide goes further with this metaphor, addressing those who have accused him of advocating violence in pursuit of greater justice:

History has proven that some wars are just. This war that I have been accused of advocating is an avoidable war, one that I and all men and women who care for peace and the well-being of our parishioners would wish to avoid. The men eating at the great table could avoid it if they wished to, and merely by the simple fraternal act of sharing: sharing wealth, sharing power, breaking bread with their brothers and sisters. But these men, among them bishops, do not wish for the well-being of their parishioners; they wish rather for their own well-being, and the well-being of those who sit at the great table... If they do not wish to share fraternally with those whom, before the world, they call brother and sister, then they must accept the fate that they have chosen. They must accept the simple fact that it is they, and not I and my colleagues, who are advocating war. (Aristide and Wilentz 1990, p. 17) 
It is not surprising that Aristide's rhetoric over his years-long direct confrontation with power and the level of his popular support energized those who had vested interests-inside and outside Haiti-to oppose him and the broad flood-rise of popular demand for more equitable distribution of wealth and power. As Alex Dupuy notes, "Because it envisioned the creation of a more egalitarian society, the Lavalas government threatened the most fundamental interests of the prebendary Duvalierist state. As such, it was to be expected that the neo-Duvalierists would oppose Aristide and try to overthrow him" (p. 101). Paul Farmer concurs, in the documentary film Aristide and The Endless Revolution, when he remarks, "When you look back at people who adopt ideas that are unnerving to the powerful - the idea, for example, that the Haitian poor just want poverty with dignity and a few basic rights (clean water, to be able to go to school, etc.), those are profoundly disturbing ideas in some circles, and they are profoundly popular ideas among the poor themselves" (Rossier 2005). Amy Wilentz reinforces this line of reasoning by noting that:

in spite of the trust he inspires in the Haitian people—or perhaps because of it_-Aristide has been seen ... as a dangerous character by outside observers: foreign diplomats, Western reporters, the Vatican ... They saw in him a kind of demagogic popular leader who would carry off a socialist revolution: "Radical firebrand" was the epithet used for Father Aristide in U.S. embassy cables. (Wilentz 1990, p. xiii)

Aristide's unrelenting verbal assaults on Haiti's "four-headed monster" ("That money which you have is not really yours. You earned it in thievery"7 ) led to the violent military assault on the presidential palace. As Dupuy describes it, "... [Aristide] became deluded by his own charismatic powers and believed that, with the masses behind him, he was invincible" (p. 130). The "army high command and the makout camp, with the support of the bourgeoisie and especially its wealthiest faction, were prepared to unleash the most brutal wave of repression, terror, and assassination against Aristide's supporters and the entire spectrum of the pro-democratic forces" (Dupuy 2007, p. 128). In response, "The makout forces in control of the armed forces ... needed no justification to act, only the right moment:

The military hierarchy was angered by Aristide's attacks against corruption and drug trafficking and was worried that the warming of relations between the Aristide government and the U.S. Embassy in Haiti would lead to even greater drug enforcement activities in the country. They were also restive about the formation of a presidential security force that would be loyal to Aristide. (Dupuy 2007, p. 130)

This first of two coups, during the first of what would be two aborted presidencies for Aristide, thus came on 29 September 1991, sweeping Aristide out and into exile after just seven months in office.

Following the 1991 military coup and during the subsequent return to a Duvalierist military dictatorship, this time under General Raoul Cédras, with the people's hope and faith both badly damaged, and with familiar fears of wanton violence refreshed, popular support for Aristide became, for a time, more safely expressed through metaphor, as in the popular Voodoo folk song "Fèy," performed by several musical groups, but most notably by the mizik rasin band RAM. As a lament-but with some optimism for the future- the lyrics refer to a fallen leaf, but the message was broadly understood in the Aristide-era context by those who heard and sang along (well enough that Cédras banned performance of the song). Translated to English, they read:

I'm a leaf.

$7 \quad$ A statement Aristide made in a speech two days prior to the 1991 coup, which Alex Dupuy indicates came when Aristide was already aware of the imminent military insurrection, and which others have pointed to as a catalyst for the coup because of its incendiary tone (Dupuy 127). 
Look at me on my branch.

A terrible storm came and knocked me off.

The day you see me fall is not the day I die.

And when they need me, where are they going to find me?

The good Lord, and St. Nicola,

I have only one son

And they made him leave the country. (Shacochis 1999, p. 47)

Funding: This research received no external funding.

Conflicts of Interest: The author declares no conflict of interest.

\section{References}

Aristide, Jean-Bertrand, and Amy Wilentz. 1990. In the Parish of the Poor: Writings from Haiti. Maryknoll: Orbis Books.

Aristide, Jean-Bertrand, and Christophe Wargny. 1993. Aristide: An Autobiography. Translated by Linda Mahoney. Maryknoll: Orbis Books.

Aristide, Jean-Bertrand. 2011. Haïti-Haitii? Philosophical Reflections for Mental Decolonization. London and New York: Routledge.

Asante, Molefi Kete. 2011. "Foreword" to Jean Bertrand Aristide, Haïti-Haitii? Philosophical Reflections for Mental Decolonization. London and New York: Routledge, pp. 1-7.

Concern Worldwide and Welthungerhilfe. 2020. Global Hunger Index. Available online: https://www. globalhungerindex.org/results.html (accessed on 8 September 2020).

Council on Hemispheric Affairs. 2010. The Tonton Macoutes: The Central Nervous System of Haitis's Reign of Terror. March 11. Available online: https://www.coha.org/tonton-macoutes/ (accessed on 5 June 2020).

Deren, Maya. 1970. Divine Horsemen: The Living Gods of Haiti. "Foreword" by Joseph Campbell. London and New York: Thames \& Hudson. First published 1953.

Dupuy, Alex. 2007. The Prophet and the Power: Jean-Bertrand Aristide, the International Community, and Haiti. Lanham: Rowman and Littlefield.

Farmer, Paul. 2006. The Uses of Haiti, 3rd ed. Monroe: Common Courage Press. First published 1994.

Greene, Graham. 1966. The Comedians. London: Penguin Books.

Gruson, Lindsey. 1989. 6 Priests Killed in Campus Raid in San Salvador. New York Times, November 17, Section A. 1.

Gutiérrez, Gustavo. 1988. A Theology of Liberation: History, Politics, and Salvation. Translated by Sister Caridad Inda, and John Eagleson. Revised Edition and Introduction. Maryknoll: Orbis Books. First published 1971.

Joseph, Celucien. 2014. Toward a Politico-Theology of Relationality: Justice as Solidarity and the Poor in Aristide's Theological Imagination. Toronto School of Theology 30: 269-300. [CrossRef]

Löwy, Michael. 1993. "Marxism and Christianity in Latin America" (transl. Claudia Pompon). Latin American Perspectives 79: 28-42.

Marsh, Sarah, and Andre Paultre. 2020. Haiti's Political Morass Fuels Growing Crisis of Hunger, Malnutrition. Reuters. February 19. Available online: https://www.reuters.com/article/us-haiti-hungerfeature/haiti-political-morass-fuels-growing-crisis-of-hunger-malnutrition-idUSKBN20D1UP (accessed on 2 August 2020).

Novak, Michael. 1984. The Case against Liberation Theology. The New York Times, October 21, Section 6. 51.

Quinn, John R. 1993. Loyola in El Salvador. New York Times, March 31, Section 4. 12.

Ramos, Aaròn. 2008. Review of the Prophet and Power: Jean-Bertrand Aristide, the International Community, and Haiti by Alex Dupuy. Caribbean Studies 36: 157-60. [CrossRef]

Rossier, Nicholas. 2005. Aristide and the Endless Revolution. Bern: Télévision Suisse-Romande (TSR).

Shacochis, Bob. 1999. The Immaculate Invasion. New York: Penguin.

United Nations. 2020. UN Data: A World of Information. Available online: http://data.un.org/en/iso/ht.html (accessed on 10 September 2020). 
Wargny, Christophe. 1993. "Introduction" to Jean-Bertrand Aristide: An Autobiography. Translated by Linda Mahoney. Maryknoll: Orbis Books, pp. 3-14.

Wilentz, Amy. 1990. "Foreword" to Jean-Bertrand Aristide. In The Parish of the Poor: Writings from Haiti. Maryknoll: Orbis Books, pp. ix-xxiv.

Publisher's Note: MDPI stays neutral with regard to jurisdictional claims in published maps and institutional affiliations.

(C) 2020 by the author. Licensee MDPI, Basel, Switzerland. This article is an open access article distributed under the terms and conditions of the Creative Commons Attribution (CC BY) license (http://creativecommons.org/licenses/by/4.0/). 